\title{
Milk Processing and Utilization in West African Sub-Region
}

\author{
Kubkomawa HI'* and Kenneth-Chukwu OM² \\ ${ }^{1}$ Department of Fisheries Technology, Federal Polytechnic, Nigeria \\ ${ }^{2}$ Department of Biochemistry and Animal Health and Production, College of Veterinary Medicine, Okpara University of Agriculture, Nigeria
}

Submission: December 06, 2018; Published: January 16, 2019

*Corresponding author: Kubkomawa HI, Department of Fisheries Technology, Federal Polytechnic, Mubi Adamawa State, Nigeria

\begin{abstract}
The objective of this paper was to review milk processing techniques and consumption rate in West African Sub-Region. The Nigerian dairy industry represents an important component of the agribusiness sector of the economy with great economic, nutritional, and social benefits. Processing of fresh milk is achieved by local techniques into various traditional milk products. About $47 \mathrm{~kg}$ of liquid milk per individual is consumed per year in Nigeria compared to an average of $25 \mathrm{~kg}$ for the sub-Saharan Africa region. Consumers display strong preference for locally produced and processed products such as nono (sour milk), kindirmo (sour yoghurt), maishanu (local butter), cuku (Fulani cheese) and wara (Yoruba cheese). The choice of preference is based on flavour, perceived nutritional value and regional customs and beliefs. Similarly, the local products are believed to be cheaper than their imported counterparts. Sour milk and local butter accounted for over $30 \%$ of all dairy products consumption. Urban household consume about $20 \%$ more dairy products than rural household. Pastoralists are mostly the producers but consume less of the products. Modern milk processing techniques and higher consumption rate should be encouraged in West African SubRegion to ensure improved human and animal productivity in the region.
\end{abstract}

Keywords: Milk processing techniques; Consumption rate; Nutritional benefits; West africa

Abbrevations: WHO: World Health Organization; FOS: Federal Office of Statistics; HTST: High Temperature Short-time Method; WAMCO: West Africa Milk Company

\section{Introduction}

Major human dietary problem in Africa and Nigeria is the gross deficiency in animal protein intake, both in quantity and quality. The low protein intake has been responsible for reduced human productivity with high incidence of infant mortality, severe malnutrition and general weakening of human body which pre-dispose people to diseases, low health status, and shorter lifespan [1]. For instance, the average consumption of animal protein per day is lower than the minimum of $35 \mathrm{~g}$ recommended by the FAO for daily maintenance [2].

Dairy products especially milk is the most complete food one can take having all the nutrients necessary for growth and development of the body. They provide the most important amino acid required for body building as well as tissues repairs in human beings. Animal protein equally supplies its own level of energy required for daily activities. It is also essential for the synthesis of certain hormones, enzymes and body products in both man and animals.

According to the Federal Department of Livestock and Pest Control Services in 1990, cattle population in Nigeria is about 13.9 million [3]. Out of this number, 13.5 million (96\%) are in the hands of the pastoralists which are managed in a traditional way. This pastoral herd is responsible for the supply of milk consumed in Nigeria. Only few imported breeds such as Friesians and Brown Swiss and their crosses are kept for experimental purposes in government owned agencies. Some few private commercial dairy farms exist in the country. These farms produce an insignificant proportion of milk in Nigeria.

In northern Nigeria, where bulk of the milk is produced, milk consumption is about $50 \mathrm{l}$ per capita per year compared to a national average of 20 to 251 per capita per year. This is four times below the minimum quantity recommended by the World Health Organization (WHO) and between 20 and 25 times less than the European average [4]. Imported products represent more than $90 \%$ of the milk consumed in Nigerian cities, and this figure rarely drops below 75\% [5]. The dependence on imported milk has become a classical vicious circle and getting out of it has becomes a problem. The traditional milk production and processing industry has not been able to fulfill the aspirations of the people in terms of quantity and quality. It is that, this paper was designed to review milk processing techniques and consumption rate in West African Sub-Region (Table 1). 
Table 1: Lactic Acid Bacteria and Their Products.

\begin{tabular}{|c|c|c|c|c|}
\hline S/N & Bacterium & $\begin{array}{c}\text { Uptimum } \\
\mathbf{T}^{\mathbf{0}}\end{array}$ & Effect & Product \\
\hline 1. & $\begin{array}{c}\text { Lactobacil- } \\
\text { lus lactis }\end{array}$ & $40-45^{\circ} \mathrm{C}$ & $\begin{array}{c}\text { Acidity, fla- } \\
\text { vor, aroma }\end{array}$ & $\begin{array}{c}\text { Yoghurt, } \\
\text { cheese, kefir }\end{array}$ \\
\hline 2. & $\begin{array}{c}\text { Lactobacil- } \\
\text { lus acidiph- } \\
\text { ilus }\end{array}$ & $35-40^{\circ} \mathrm{C}$ & Acidity & $\begin{array}{c}\text { Yoghurt, } \\
\text { Acidiphilus, } \\
\text { butter milk }\end{array}$ \\
\hline 3. & $\begin{array}{c}\text { Streptococ- } \\
\text { cus lactis }\end{array}$ & $30^{\circ} \mathrm{C}$ & Acidity & $\begin{array}{c}\text { Cheese, sour } \\
\text { cream, acid } \\
\text { butter milk }\end{array}$ \\
\hline 4. & $\begin{array}{c}\text { Streptococ- } \\
\text { cus thermo- } \\
\text { philes }\end{array}$ & $40-45^{\circ} \mathrm{C}$ & Acidity & $\begin{array}{c}\text { Yoghurt, } \\
\text { cheddar, } \\
\text { cheese }\end{array}$ \\
\hline 5. & $\begin{array}{c}\text { Leuconostoc } \\
\text { citrovorum }\end{array}$ & $20-25^{\circ} \mathrm{C}$ & Flavor, \\
aroma & $\begin{array}{c}\text { Butter, sour } \\
\text { cream, acid } \\
\text { butter milk }\end{array}$ \\
\hline
\end{tabular}

\section{Dairy Industry in Nigeria}

According to FAO [6] report, the dairy industry provides a means of livelihood for a significant proportion of pastoral families in Nigeria. For instance, about 183,000 rural households were said to have derived some income from the dairy industry in 1986. This ability of the dairy enterprise to generate regular income and to contribute to the household diet on a regular basis throughout the year is an advantage over other agribusiness enterprises [7]. In addition, apart from providing employment to the processors, it also provides income to informal milk traders, cooperatives and others who have any dealing with the milk markets. Estimates from vaccination, cattle tax and sample surveys put the cattle population in Nigeria at about 12 million [8], while the Federal Office of Statistics [9] put it at 16 million. About 96 percent of the total cattle population in Nigeria is believed to be in the hands of pastoralists [3], who are predominantly Fulanis, the Shuwa Arabs, and the Bororos. Consequently, they are the most important source of domestic milk in Nigeria [10]. These herdsmen practice a traditional type of management whereby cattle are held in the vicinity of the village or urban areas during the wet season and then taken to lower pastures during the hot months in search of greener grazing areas [11].

\section{Milk Consumption}

Milk is a fluid food produced in the mammary gland of female animals following parturition. It is an emulsion of butter fats and water. The aqueous phase contains proteins, lactose, minerals, enzymes and vitamins as shown in Figures 1-3 [12]. Dairy products consumption in Nigeria is higher than the average consumption by the sub-Saharan African consumption. About $47 \mathrm{~kg}$ of liquid milk per individual is consumed per year in Nigeria compared to an average $25 \mathrm{~kg}$ for the sub-Saharan Africa region. Consumers display strong preference for locally produced and processed products such as milk, butter and yoghurt. The choice is based on flavor, perceived nutritional value and custom. The local products are also much cheaper than their imported counterparts. Sour milk and local butter accounted for over $30 \%$ of all dairy products consumption. Urban household consume about $20 \%$ more dairy products than rural household. Pastoralists are mostly the producers but consume less of the products. The bulk of the milk produced by Pastoral Fulanis are sold to urban duelers for exchange of money, grains and other life necessities [12].
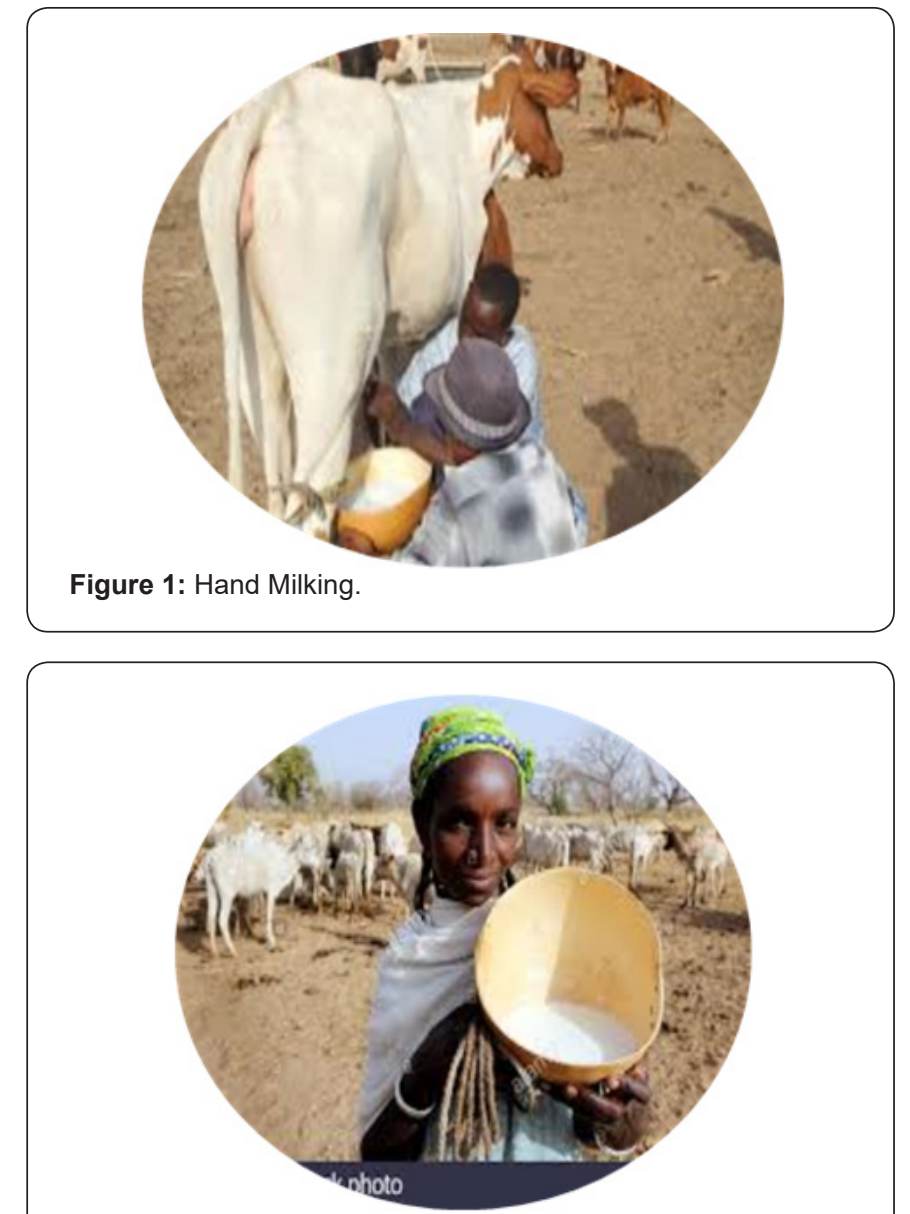

Figure 2: Hand Milking Nono.

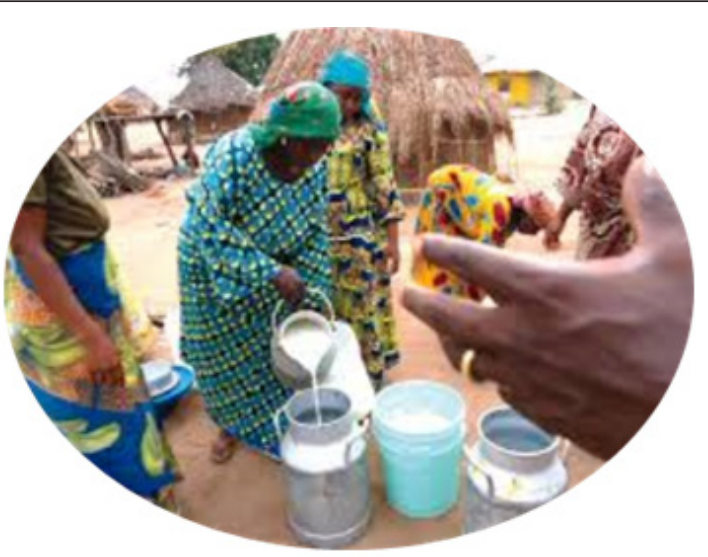

Figure 3: Coalition of Fresh Milk. 


\section{Dairy Chemistry and Nutritive Value}

\section{Physical Properties of Milk}

Since milk is $87 \%$ water, its physical properties are essentially those of water, modified to some extend by the concentration and state of dispersion of solid constituent. The measurements of physical properties are useful in quality control and to detect variation from the normal in case of deterioration. It is also useful in the design of dairy equipment and in detecting adulteration of milk [12].

Milk is heavier than water because of the dissolved constituents. The degree of acidity or alkalinity is termed PH. The PH of 7 neutral, less than 7 is acidity and more than 7 is alkalinity. Therefore, milk has a PH of $6.5-6.7$ and is slightly acidic. The freezing point of milk is -0.54 to $-0.59^{\circ} \mathrm{C}$ and the boiling point of milk is $100.17^{\circ} \mathrm{C}$. The colour of milk ranges from white to yellow or cream color [12].

\section{Chemical Composition of Milk and Milk Products}

According to Olawoye and Kubkomawa, the average composition of cow milk is as follows: Water (87\%), Fats $(2.9 \%)$, Lactose (4.9\%), Proteins (3.5\%) and Ash (0.7\%). The total solid is $13 \%$ while non-fat solid is $9 \%$. There is, however, variation in composition of milk between animal species. Milk composition differs between breeds and putting breeds of the cow may also vary between one milking and the next and udder quarters, even in the same animal. Other factors determining milk is the plane of nutrition, temperature, availability of water, length of lactation, health of the animal, management and age of the animal [12].

\section{Milk Products Processing}

It is the application of some treatments to raw milk to make it safe for human consumption or to convert to other desirable products. Such treatment could involve heating and cooling for separation of milk constituent or formulation [12].

\section{Reason for Milk Processing}

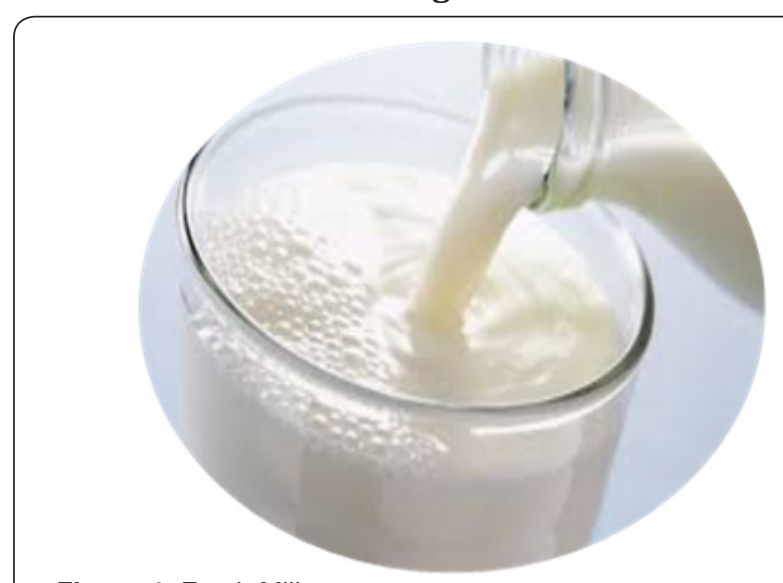

Figure 4: Fresh Milk.

Milk produced from udder of cow has different bacteria, some could cause disease or they are pathogenic, this disease could enter the milk through flies, contaminated water or utensils. The most obvious reason for processing is to safeguard the public health through parturition or sterilization of milk and milk products. This ensures elimination of disease-causing bacteria. Other reasons for processing are to get evaporated and condensed milk, this will reduce the cost of transportation because you have reduced the quantity of water. It also reduces storage spaces. Processing also produces cream which is used for ice cream. The milk protein, casein is processed into cheese of different varieties. Another reason for processing is to conform to industry and health regulations, for example, in countries where dairy products are inspected before they are sold, unprocessed dairy product will not be passed for sale if set safe standards are not met. Such standards require some degree of processing. Examples of dairy products are fresh milk, fermented milk, cheese, yoghurts and whey as shown in Figures 4 \& 5 [12].

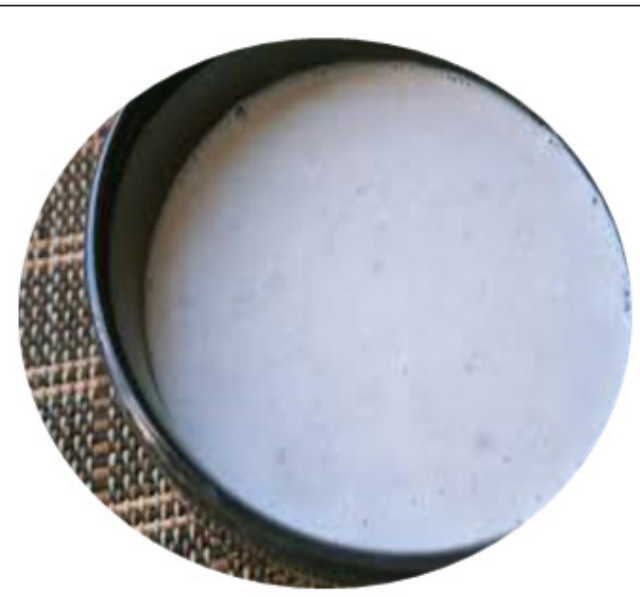

Figure 5: Fermented Milk (Fura da Nono).

\section{Pasteurized Milk}

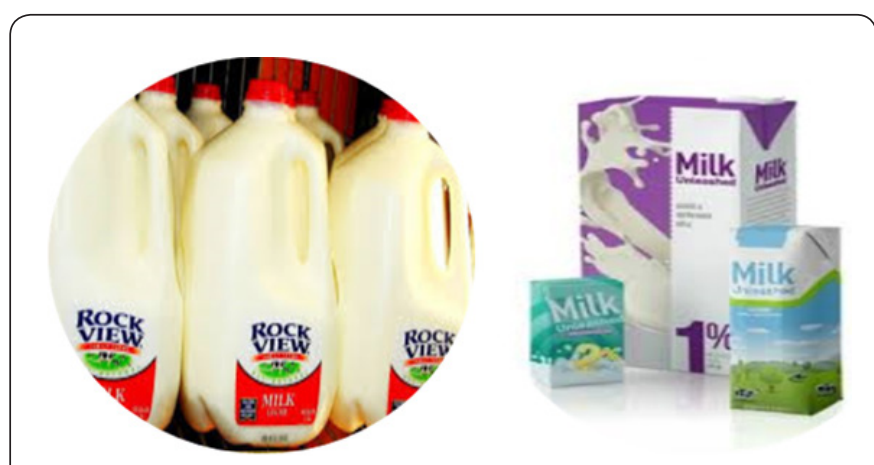

Figure 6: Pasteurized Milk.

According to Olawoye and Kubkomawa, pasteurized milk is a process by which milk or milk products are heated to a specific temperature and held there for a specific time to destroy all pathogenic bacteria as shown in Figures 6.

Two methods are employed in pasturalization this includes:

The Holding, Vat or batch Method: Raw milk is heated in a container to at least $62^{\circ} \mathrm{C}$ and holding at such temperature for 30 minutes. The milk is then cooled for packaging. 
The High Temperature Short-time Method (HTST): Milk is heated to at least $72^{\circ} \mathrm{C}$ and holding at that temperature continuously for at least 15 seconds in an approved and properly operated equipment, such as plate or tube-type pasteuriser. The milk is pumped through heat exchanger where it has contact with heat for 15 seconds and the milk is then cooled and packaged. Pasteurization kills about $99.6 \%$ of all bacteria [12].

Sterilization or sterilized milk: It is a product obtained from raw milk that is heated to a high temperature of $92.4^{\circ} \mathrm{C}$ - $97.0^{\circ} \mathrm{C}$ for long periods of $15-30$ minutes so that all microorganisms, both pathogenic and non-pathogenic are destroyed. Generally, the batch method or continuous flow method at ultrahigh temperature is used. The flavor of sterilized milk is not pleasant and heating at such a high temperature might result in a decrease in the vitamin content [12].

\section{Evaporated milk}

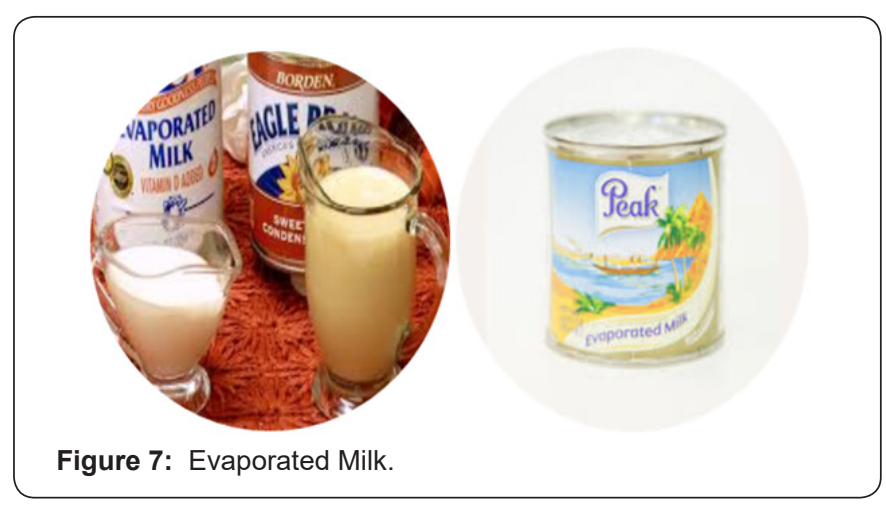

It is made by evaporating water from whole milk at $70.4^{\circ} \mathrm{C}$ $-73.2^{\circ} \mathrm{C}$ in a vacuum. About $50 \%$ of the water in the original milk is boiled off. This process can be achieved in the house by slowly evaporating water from milk in a pot, or the pot is placed in a water bath until the milk smells like evaporated milk popularly known as peak milk or carnation brand. Industrially, the concentrated milk is filled into tins and sterilized under pressure at $116^{\circ} \mathrm{C}$ for 15 minutes to kill all micro-organisms and in-activated enzymes as shown in Figure 7.

\section{Condensed milk}

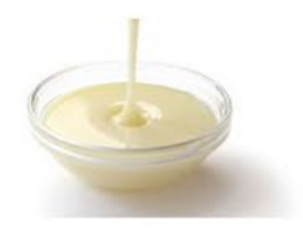

Figure 8: Condensed Milk.

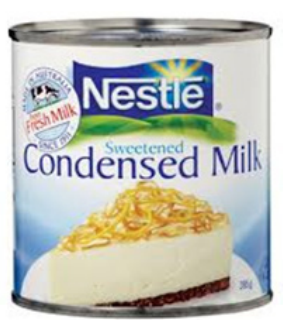

The product is obtained by concentrating whole milk under a vacuum to concentration ranging from 2.5: 1 to $4: 1$. The usual ratio is $2.8: 1$. This means 2.8 volume of milk or its multiple is evaporated until one volume remains. About $18 \%$ sugar in the form of sucrose is added and the product is termed sweetened condensed milk as shown in Figure 8.

\section{Skimmed milk}

Skimmed milk is defined as milk from which an enough proportion of milk fat has been reduced in order to reduce its milk fat content to less than the minimum for whole milk. Skimmed is also designated as non-fat, fat-free or defatted milk. It can stay for 16 months without spoilage before fat is removed and fewer mediums for bacteria growth are removed but, whole milk stays only 10 months as shown in Figure 9.

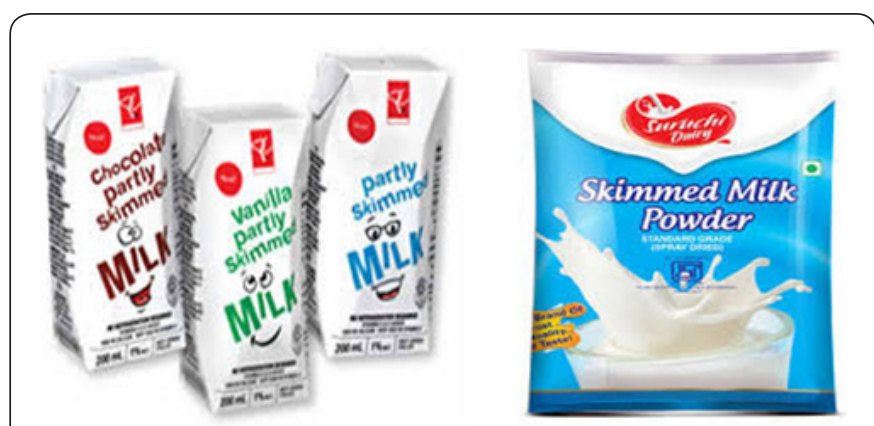

Figure 9: Skimmed Milk.

\section{Butter}

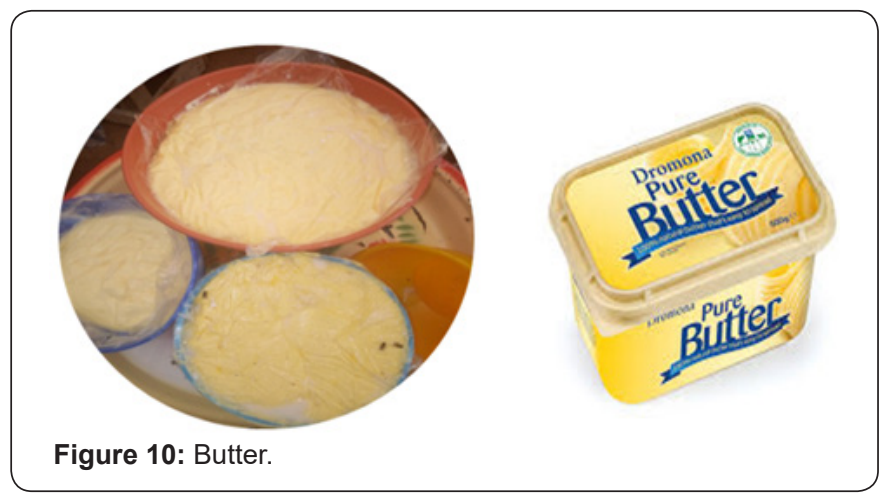

When cream is agitated by churning, large chumps form to yield butter. This is because fat particles have mucin-like materials which are sticky; agitation causes large chumps to form. This chump of yellow fat form is called butter. A vessel in which cream is agitated is called the churn and churning is the process or the act of operating the churn. Cream is put into a churn where it is subjected to mechanical agitation. In a short time, yellowish granular appears, which is the first form of butter. The liquid is drained off and the granules are washed several times too with clean cold water. The granules are worked or kneaded into a solid mass which is called butter. During the kneading process, $1-2 \%$ salt is added by weight to enhance flavour of butter, the butter is then cut into rectangular shape and wrapped in water proof material and stored in a cool place. Butter contains about $80 \%$ fats, $16 \%$ water, $1 \%$ curd and $2.5 \%$ salt. The first liquid drained from butter after churning is called butter milk; in India butter oil is called Gee as shown in Figure 10. 


\section{Cheese}

Cheese is the product made from the separated curd obtained by coagulating the caesin of milk, skimmed milk or milk enriched with cream. Curd is the coagulated part of milk or coagulum. The coagulation is accompanied by means of rennin or other suitable enzymes, lactic acid, fermentation or by the combination of the two. The curd may be modified by heat, pressure, ripening ferments, special mould or suitable seasonings. Cheese is a complex food product consisting mainly of casein, fat and water. The percentage of fat in cheese is influenced to the greatest degree by the percentage of fat in milk used for its production as shown in Figures 7-9.

Figure 11: Cneese.
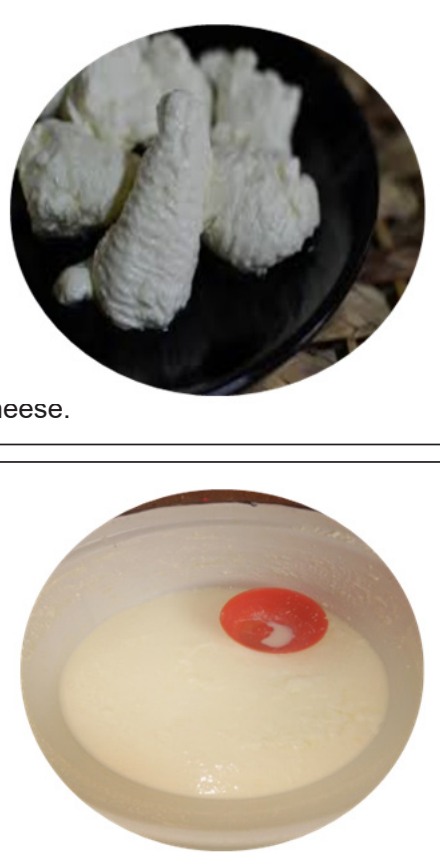

Figure 12: Fermented Milk (kindirmo).

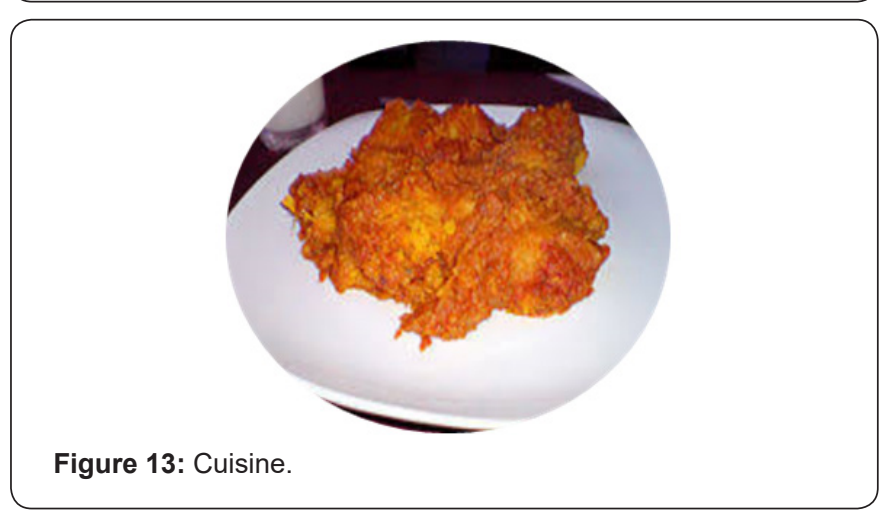

There are several ways of making different kinds of cheese. Basically, there are two (2) common procedures required for most cheese making: Production of coagulum or curd and curing. A pure culture of specific bacteria is added to the milk to produce a desired acidity and flavor. A protein coagulant (rennin) is added to precipitate the protein which forms the body of the cheese. After precipitation of milk solids (cured formations), the liquid which remains is called whey. This is drained off and the curd is washed thoroughly with clean cold water. The cheese is put into cheese cloth and the water is pressed out. About $2-5 \%$ salt is added and the cheese is formed into specific shapes and stored for several weeks to develop characteristic flavor. Coloring agents may be added to the cheese (Figures 11-13).

\section{Milk Micro-Biology, Quality and Control}

Fresh milk from healthy udder contains very few bacteria. The bacterial load is about $500-1000 / \mathrm{ml}$. Milk will be contaminated with bacteria after it is drawn from the udder, the number of bacteria will increase greatly during holding and transportation. The rate at which organisms multiply depends on temperature of the milk and species of bacteria present. Under normal circumstances, milk will stay for a period of 72 hours when it is kept at $4^{\circ} \mathrm{C}$. The multiplication is also influenced by the degree of bacterial contamination in the milk. Sources of bacteria in milk are: through the hair of the animal, the dung, air, feed-stuff, soil, milk handling equipment and the milker's cloth, hair of the milker and other activities. Milk is a very good nutrient medium and once micro-organisms enter the milk, their numbers increase rapidly.

\section{Bacterial Action in Milk}

There is a decrease in the number of bacteria in milk for a period after it has been drawn from the udder. This is determined by plate count. This action lasts for about 3 hours after the milk has been drawn. High temperature of $59^{\circ} \mathrm{C}-79^{\circ} \mathrm{C}$ for 30 minutes appear to destroy the germicidal property of milk. Bacterial action in milk is due to unfavorable conditions which kill the bacteria. Some bacteria may be ingested by the leukocytes in the milk. Bacterial action in raw milk has little or no effect on streptococcus lactose bacteria and acid producing bacteria. This situation enables the lactic acid bacteria to ferment lactose in milk to enough acidity, which prevents growth of the bacteria and any other pathogenic bacteria. The lactic acid prevents the growth of most types of bacteria most likely to be present and thus act as a preservative.

\section{Types of Bacteria in Milk}

The most important bacteria in milk are the lactic acid producing bacteria. The principal lactic acid producing bacteria includes Streptococcus lactic spp and genus Lactobacillus.

The bacteria and the products they produce are as follows:

\section{Pathogenic bacteria in milk}

There are 2 methods by which pathogenic bacteria enter milk and cause epidemic. It could enter through the udder of the cow and the organisms include; Mycobacterium tuberculosis, var-bovis, brucella; Coxiella burnettr (the rickettsiae of fever) and streptococcus pyogenis. Through infected persons or other vectors that may introduce the bacteria into the milk, which are Salmonell shigella, Streptococcus pyrogen, Conynebacterium diptheriae and Staphylococcus aureus. Others include yeast and 
mould that may be present in the milk. Yeast and mould are regarded as contaminants in milk and its products, there are also contaminants from the air and can grow on sour milk, they utilize some of the acid and produce a decrease in the acidity and shelf life of sour milk. This pre-dispose the milk to rapid composition of milk proteins by growth of putrefying bacteria [12].

\section{Milk hygiene}

There is the need to keep good sanitary measures in any dairy industry, therefore, the equipment is supposed to be sterilized based on the following steps:

a. Steam sterilization of equipment; if you are using autoclave or steamships chest, steam can induce a moist treat high enough to kill all bacteria.

b. Hot water sterilization of equipment; this is a physical cleaning which removes visible dirt as well as sterilizing the equipment, the water temperature must be $92.4^{\circ} \mathrm{C}$ and last for five minutes.

c. Chemical sterilization; this is bacteriological cleaning attained by chemicals sterilization. Chemicals of the halogen group, bromine, fluorine, iodine have been used. Chlorine and other chemicals make the best bactericide for sterilizing milk equipment.

d. It is expected that, after milking, the equipment should be cleaned thoroughly with the chemicals stated above.

\section{Procedures in Cleaning Dairy Equipment}

Rinse and flush equipment with simple amount of cool cleaning water. For hand cleaning, use fibre or nylon bristle brushes, the water should be hot $\left(43-48^{\circ} \mathrm{C}\right)$. Circulating method of cleaning: Rinse or flush through system until the rinse water shows up clear at the discharge. Add phosphoric acid and water and heat to $70.4^{\circ} \mathrm{C}$ and make sure it circulates through the equipment for 30 minutes. Flush again with clean cool water in order to ensure that, there is no acidic taste. Add an alkaline detergent and flake caustic soda and clean equipment again. Flush very well with clean water until there is no "slippery" feel to the water and it does not taste bitter. Drain equipment and let it stand until it is sterilized prior to use [12].

\section{Marketing of Milk and Milk Products}

Milk is sold in the village level in the raw form as madara or locally processed in to kindirmo and nono and hawked around by the Fulani women and girls. This happens, usually, at the onset of the rains when the product is bountiful [12]. They also organize dealers who go around from village to village to buy the milk and ship it to places where its lacking, e.g. the Fulani women who use to transport the product from Maiduguri, Borno State to places like Adamawa and even down to the far East and West. There are also some locally installed industries, e.g. Nagge and Adama Beverages in Yola who buy the product and process it into yoghurt and sell to consumers. There are also some retailers, usually at the motor parks who buy the milk from the dealers and stock it into chill ice milk for customers and travelers. But matured and well-established companies like West Africa Milk Company (WAMCO) Vom, produces, processes and sells to the consumers finished products like peak, cheese, yoghurt, butter etc.

\section{Conclusion and Recommendations}

There are poor dairy processing technologies and consumption rate in Nigeria and elsewhere in West African SubRegion. Dairy processing techniques are not well developed with traditional methods being the common feature. This traditional industry processes these products into 'nono' (fermented milk), fura da nono, kindirmo, yoghurt, cheese and market them in semi-urban and urban cities. Other factors responsible for low consumption of the products include the poor socio-economic status of the people. In order to promote the processing techniques and consumption rate, there should be sustained dairy technologies provided by government and the private sectors. This will enhance productivity, raise living standard of the populace, and reduce poverty and diseases around the continent.

\section{References}

1. Mbanasor JA (2002) Respurce Use Pattern among Poultry Enterprises in Abia State, Nigeria. Nigerian Journal of Animal Production 29 (1-2): 63-70.

2. Bincan JN (1990) A Review of Government Policies and Programmes for Livestock Development in Nigeria. A Paper Presented at the National Conference on Livestock Industry and Prospects Held at Lugard Hall, Kaduna, Nigeria.

3. RIM (1990) Resource Inventory and Management. Livestock resource survey.

4. Annatte I (2010) Nigeria- Milk Production Fact Sheet. In: IFCN Dairy Report 2009, International Farm Comparison Network, Dairy Research Center, Kiel, Germany 3(63): 129.

5. Land O (2007) Dairy Enterprise Initiative Programme-Nigeria, pp.37.

6. FAO (1988) The milk and dairy market. Agricultural Review for Europe, Food and Agriculture Organization, Europe.

7. Muriuki HG (2001) Smallholder dairy production and marketing in Kenya. In: Rangnekar and Thorpe (Editors) Small holder dairy production and marketing: opportunities and constraints. Proceedings of a South-South workshop held at National Dairy Development Board (NDDB), Anand, India, pp. 13-16.

8. Adegbola AA (1990) Livestock development and nutrition in Nigeria. In: Ikeme (Eds.), challenges of agriculture for national development. Optimal Computer Publishers, Enugu, Nigeria.

9. FOS (1994) Annual abstract of statistics. Abuja, Federal Office of Statistics (FOS).

10. Yahuza ML (2001) Smallholder dairy production and marketing constraints in Nigeria. In: Rangnekar \& Thorpe (Eds.), Small holder dairy production and marketing: opportunities and constraints. Proceedings of a South-South workshop held at National Dairy Development Board (NDDB), Anand, India, pp. 13-16. 
11. Douffissa A (1993) Cattle production in the Mbere (Cameroon, Adamaoua) Collection etudes et thèses. Editions de l'ORSTOM, Paris, France, pp. 281.
12. Osotimehin KO, Tijani AA, Olukomogbon EO (2006) An economic analysis of small-scale dairy milk processing in Kogi State, Nigeria. Livestock Research for Rural Development 18: 11.

\section{Your next submission with Juniper Publishers will reach you the below assets}

- Quality Editorial service

- Swift Peer Review

- Reprints availability

- E-prints Service

- Manuscript Podcast for convenient understanding

- Global attainment for your research

- Manuscript accessibility in different formats

( Pdf, E-pub, Full Text, Audio)

- Unceasing customer service

Track the below URL for one-step submission https://juniperpublishers.com/online-submission.php 